\title{
Iron Ore Tailings: Characterization and Applications
}

\author{
Ottávio R. Carmignano, ${ }^{\#, a}$ Sara S. Vieira, ${ }^{\oplus *, \#, b, c}$ Ana Paula C. Teixeira, ${ }^{b}$ \\ Fernando S. Lameiras, ${ }^{d}$ Paulo Roberto G. Brandã ${ }^{e}$ and Rochel M. Lago ${ }^{\oplus} * b$
}

\begin{abstract}
${ }^{a}$ Doutorado em Inovação/Mineradora Pedras Congonhas, Universidade Federal de Minas Gerais, 31270-901 Belo Horizonte-MG, Brazil

${ }^{b}$ Departamento de Química, Universidade Federal de Minas Gerais, Pres. Antônio Carlos, 6627, 31270-901 Belo Horizonte-MG, Brazil

'Departamento de Química Inorgânica, Instituto de Química, Universidade Federal Fluminense, Miguel de Frias, 09, 24220-900 Niterói-RJ, Brazil
\end{abstract}

${ }^{d}$ Centro de Desenvolvimento da Tecnologia Nuclear, Pres. Antônio Carlos, 6627, 31270-901 Belo Horizonte-MG, Brazil

${ }^{e}$ Escola de Engenharia, Universidade Federal de Minas Gerais, Pres. Antônio Carlos, 6627, 31270-901 Belo Horizonte-MG, Brazil

\begin{abstract}
Currently, approximately 1.4 billion tons per year of iron ore tailing wastes (IOT) are generated, mainly in Australia, Brazil, and China. This work describes the characterization and application of two typical IOT, i.e., fine and coarse wastes. The physicochemical characterization of these IOT by different techniques such as XRF (X-ray fluorescence), XRD (X-ray diffraction), Mössbauer spectroscopy, and granulometry, indicates for the fine tailing a composition of $\mathrm{Fe}_{2} \mathrm{O}_{3} / \mathrm{FeOOH}$ (10-55\%), $\mathrm{SiO}_{2}(18-65 \%)$ and $\mathrm{Al}_{2} \mathrm{O}_{3}$ (up to $15 \%$ ) with particles of 6-40 $\mu \mathrm{m}$, whereas the coarse tailing presents $40-150 \mu \mathrm{m}$ particles with the composition of $8-48 \% \mathrm{Fe}_{2} \mathrm{O}_{3} / \mathrm{FeOOH}, 30-90 \%$ $\mathrm{SiO}_{2}$ and $\mathrm{Al}_{2} \mathrm{O}_{3}$ (up to 20\%). The main IOT applications discussed in this review are related to civil construction (aggregates for concrete, mortar, Portland cement additives), ceramic industry, geopolymer, synthesis of new materials such as zeolites, mesoporous silica, carbon nanotubes, adsorbents, catalysts for different reactions, in batteries and in fuel cells. It was also carried out an analysis of patents related to IOT applications and the main technological and market barriers that hinder the industrial and commercial uses of these wastes.
\end{abstract}

Keywords: iron ore tailings, mining waste, iron oxide, technological application

\section{Introduction}

Iron is the fourth most abundant element and accounts for about $5 \%$ of the Earth's crust. Commonly found in the form of ore, iron has been used for over four thousand years in the fabrication of tools and weapons. Iron ore is an essential part of the manufacture of steel and it is difficult to imagine modern society without it. ${ }^{1}$ The main deposits of iron ore are found in Australia, Brazil, Canada, India, China, Europe, and South Africa as shown in Figure 1. ${ }^{2}$

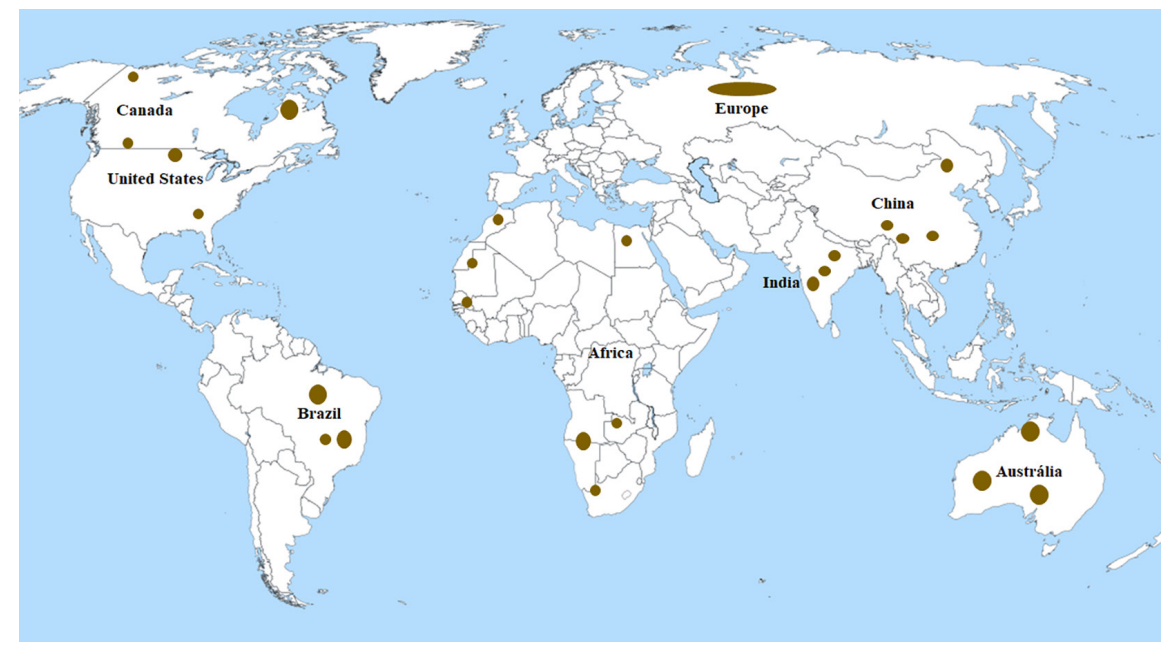

Figure 1. World map indicating the location of economic iron oxide deposits (adapted from references 2,3).

*e-mail: saraquimica85@gmail.com, sarasilveira@id.uff.br; rochel@ufmg.br

"These authors contributed equally to this work. 
According to the USGS (U.S. Geological Survey) Mineral Commodity Summaries 2020, ${ }^{4}$ the crude iron ore reserves in the world are 170 billion tons. Brazil has 30 billion tons of iron reserves, second only to Australia (48 billion tons). ${ }^{5}$ In 2018, Brazil marketed 515 million tons of mineral products, according to the mineral yearbook of the main Brazilian mineral substances. ${ }^{5}$ The Brazilian iron ore production, in this same year, was around 450 million tons. ${ }^{5}$ According to the Brazilian mineral yearbook of the main metallic substances of $2020,{ }^{6}$ the gross production of iron ore in 2019 in Brazil was 510 million tons (about 400 million tons benefited).

The most important states for iron mining in Brazil are Minas Gerais and Pará, which contributed to 58 and $40 \%$ of the iron gross production in 2018, respectively. ${ }^{5}$ The Quadrilátero Ferrífero (Minas Gerais-MG) is considered the most important producer of iron ore in Brazil, exporting about $51.6 \%$ of ore. ${ }^{7,8}$ In 2018/2019 the State of Minas Gerais extracted approximately 180 million tons per year of iron ore. ${ }^{8}$ In 2020, mining company Vale S/A produced around 330 million tons. In the Brazilian states of Minas Gerais and Pará, production in 2020 was approximately 203 and 188 million tons, respectively. ${ }^{6}$

In Brazil, the two most important iron ore types are hematite rich and itabirite (banded iron formations (BIF)). Hematite rich type is extracted mainly in the state of Pará and has an average iron content higher than $60 \%$. Itabirite, on the other hand, is mined mainly in the Quadrilatero Ferrífero (MG) and shows an iron content of around $50 \% .^{9}$ In both cases, these rocks are mainly composed of hematite $\left(\alpha-\mathrm{Fe}_{2} \mathrm{O}_{3}\right)$. However, magnetite $\left(\mathrm{Fe}_{3} \mathrm{O}_{4}\right)$, and goethite $(\alpha-\mathrm{FeOOH})$ are also found with a considerable concentration of iron in their composition. Other minerals, which do not contain a significant amount of iron and also occur in the ores are called gangue. In the Brazilian ores, the main gangue minerals are quartz $\left(\mathrm{SiO}_{2}\right)$; kaolinite $\left(\mathrm{Si}_{2} \mathrm{Al}_{2} \mathrm{O}_{5}(\mathrm{OH})_{4}\right)$, which introduces alumina $\left(\mathrm{Al}_{2} \mathrm{O}_{3}\right)$ and silica; gibbsite $\left(\mathrm{Al}(\mathrm{OH})_{3}\right)$, also bringing in $\mathrm{Al}_{2} \mathrm{O}_{3}$. Other minor chemical compounds, such as calcium, magnesium, manganese, sulfur $(\mathrm{S})$, and phosphorus $(\mathrm{P})$ minerals, can also be present in both ores mined in the reserves of Pará and Quadrilátero Ferrífero. ${ }^{10}$

\subsection{The iron ore beneficiation process}

There are different types of iron beneficiation processes. The choice of the process depends on the mineral composition, iron content, and degree of liberation of iron from gangue minerals. ${ }^{11}$ The most common beneficiation processes are magnetic separation, flotation, reverse flotation, electrostatic separation, gravity methods, and flocculation. ${ }^{12-16}$

In general, the processing of iron ore involves operations to modify the particle size distribution and to increase the iron content, without changing the chemical or physical identity of the minerals. ${ }^{13}$ In ores where the iron content is already high (e.g., Carajás-Brazil), the processing, normally, is a simple grinding and separating by size to obtain a product ready for sale. ${ }^{15}$ However, BIF ore requires concentration steps because the separation by size is not capable of generating products with high iron contents. The problem is that these steps, generally, are carried out with water, which can generate a large number of tailings.

In a typical iron beneficiation process in Quadrilátero Ferrífero, MG, the processing begins with the extraction stage, usually an open-pit mine. In industrial plants, the ore mined is crushed, ground, sieved and separated from a silica rich phase through the reverse flotation process. After this stage, the ore, now transformed into a pulp, has reached the necessary chemical and physical specifications for subsequent industrial processes. ${ }^{14,15}$ Figure 2 illustrates a typical flow chart for the treatment of ores, according to the Mining Regulatory Standard (NRM-18). ${ }^{17}$

In flotation, the hydrophobic/hydrophilic character of the minerals is altered by the addition of specific reagents such as sulfur derived compounds, fatty acids, amines, and starch. These chemicals can be divided into collectors, depressants, frothers, and modifiers or regulators. ${ }^{18}$

Typical iron ore, with low iron content, requires a concentration method based on reverse cationic flotation, in which quartz is recovered from the foam and iron oxides remaining in the pulp phase. ${ }^{15,18}$ This is the most common separation process used for the itabirite iron ore.

During the iron minerals extraction from BIF, two types of non-economical tailing materials called generically

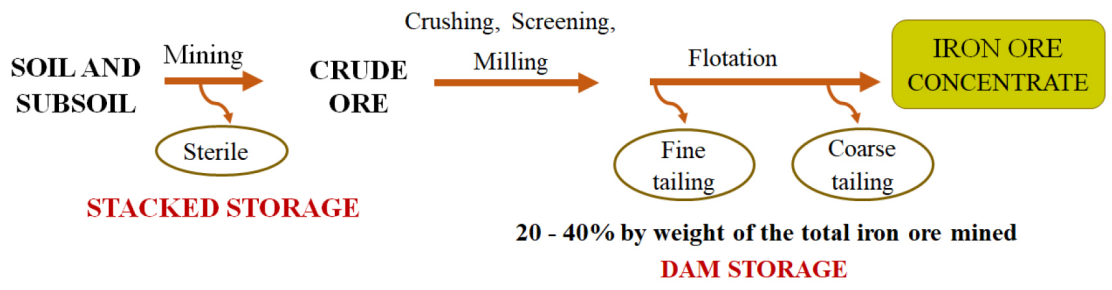

Figure 2. Stages of the iron ore beneficiation process, using flotation methodology. 
iron ore tailings (IOT) are generated, i.e., a coarse tailing, generated in the flotation stage, consisting mainly of quartz, and a fine tailing, whose main components are usually quartz, hematite, goethite, and kaolinite. The fine tailing is generally generated during the step of desliming, which happens immediately before flotation. In Brazil, the generation of iron ore tailings (coarse or fine tailing) is estimated at $20-40 \%$ by the weight of the total iron ore mining. ${ }^{13,18}$

1.2. Generation iron ore tailings (IOT) and environmental problems

Iron mining is of great importance for economic development, however, it generates a huge extension of drastically altered areas ${ }^{19,20}$ and several billions of tons of mine tailings annually worldwide.

According to the FEAM (Minas Gerais State Environmental Agency), ${ }^{8}$ in 2017, 562 million tons of mining tailings were produced, only in the state of Minas Gerais, Brazil. China generates 1.5 tons of iron ore tailings for each ton of iron ore concentrate..$^{21,22}$ In this country, the annual production of iron ore tailings reaches about 180 million tons and is increasing. ${ }^{23}$ In India, between 10-12 million tons of iron ore tailings are extracted in the form of ultrafine waste..$^{24}$ In Australia, it is estimated that about 632 million tons of iron ore tailings are generated each year. ${ }^{25}$ In countries such as Canada, the United States, and Africa, the amount of iron mining waste generated annually is less than 1 million tons (Figure 3), ${ }^{2,26}$

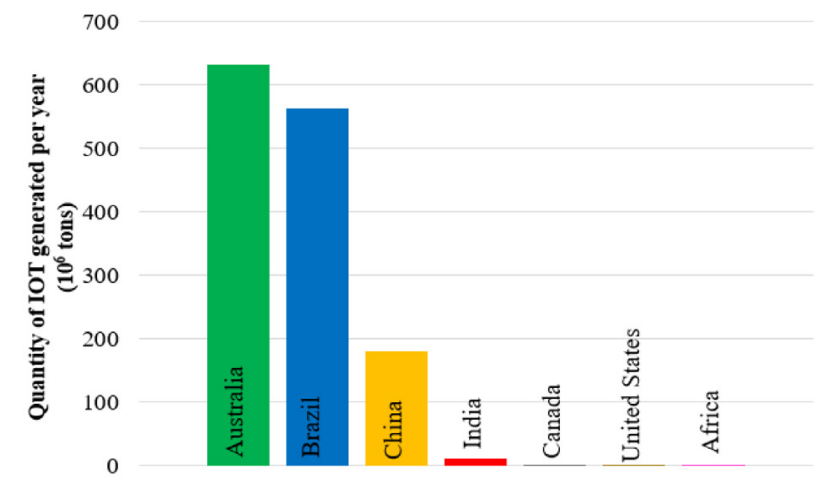

Figure 3. Amount of iron ore tailings generated annually in different countries.

In Brazil, around $95 \%$ of mining tailings are destined to 672 containment dams, ${ }^{8,27} 340$ of them are located in the State of Minas Gerais. ${ }^{27}$ Between 2015 and 2019, more than 10 disasters related to dam breaks occurred in several countries (Brazil, United States, Canada, China, and Peru). ${ }^{28}$ The rupture of the Fundão Dam (Mariana, MG) in 2015, released more than 30 million $\mathrm{m}^{3}$ of water and tailings from the extraction of iron ore, into the environment. This disaster, in addition to causing serious environmental damage, killed 19 people. ${ }^{29-31}$ Another serious iron ore tailings dam break occurred in 2019, in the city of Brumadinho (Minas Gerais, Barragem do Feijão). This accident killed 257 people and caused untold environmental impacts. At least 12 million $\mathrm{m}^{3}$ of ore tailings have been spread around the Paraopeba river. ${ }^{19,32}$

\section{Physicochemical Characterization of Iron Ore Tailings}

The chemical and mineralogical composition of the IOT generated in the iron ore beneficiation process depends mainly on the mineralogy of the processed rock, the nature of the processing fluids used in the target minerals, the efficiency of the processing, and the degree of weathering before the storage in the dam. ${ }^{29}$

During the exploitation of iron ore, crushing rocks generates particles of iron oxide, quartz, and clay. Depending on the granulometric classification, the tailings can be classified as fine or coarse waste (granular or sandy tailings). Iron ore with high clay content, for example, tends to generate fine particles. ${ }^{33}$

Fine tailings are usually originated from the beneficiation process that involves desliming. These tailings, in general, are extremely fine, characterized basically by size fractions corresponding to the clay (with more than $90 \%$ below $74 \mu \mathrm{m}$ in diameter). ${ }^{10}$

The flotation produces a coarse tailing made mainly of $\mathrm{SiO}_{2}$ with small amounts of iron oxide, hydroxide, and kaolinite with an average particle size of $150 \mu \mathrm{m} .{ }^{34} \mathrm{In}$ terms of mineralogy, most coarse tailings are mainly composed of quartz and small amounts of hematite and goethite.

An important parameter that must be obtained from the characterization of the IOT is the water content. Most published works indicated that the amount of water is less than $15 \% \%^{10,35-37}$ for the coarse IOT. The fine IOT water content is generally higher than $20 \%{ }^{38}$

One of the main techniques used to study the chemical composition of the IOT is X-ray fluorescence (XRF). Results of chemical analyzes, using XRF, of iron ore tailings from different works in the literature are presented in Table 1.

The coarse IOT assessed by Melo et al..$^{39}$ consisted mainly of $\mathrm{SiO}_{2}(84 \%)$ and small fractions of $\alpha-\mathrm{Fe}_{2} \mathrm{O}_{3}$ $(12 \%)$. The chemical composition of the sandy tailings characterized by Zuccheratte ${ }^{34}$ showed about $49 \% \mathrm{SiO}_{2}$ and $29 \% \alpha-\mathrm{Fe}_{2} \mathrm{O}_{3}$. Results of X-ray diffraction analysis for tailings of this nature indicate the presence of phases of quartz $\left(\mathrm{SiO}_{2}\right)$, hematite $\left(\alpha-\mathrm{Fe}_{2} \mathrm{O}_{3}\right)$, goethite $(\alpha-\mathrm{FeOOH})$, and magnetite $\left(\mathrm{Fe}_{3} \mathrm{O}_{4}\right)$; the latter is usually very low concentration in the commercial Brazilian ores. ${ }^{19,39-41}$ 
Table 1. Main chemical composition obtained by XRF (X-ray fluorescence) of different iron ore tailings (IOT)

\begin{tabular}{|c|c|c|c|c|c|c|c|}
\hline \multicolumn{6}{|c|}{ Main chemical composition / \% } & \multirow{2}{*}{ Mine location } & \multirow{2}{*}{ Reference } \\
\hline $\mathrm{Fe}_{2} \mathrm{O}_{3}$ & $\mathrm{SiO}_{2}$ & $\mathrm{Al}_{2} \mathrm{O}_{3}$ & $\mathrm{CaO}$ & $\mathrm{MgO}$ & Other compounds & & \\
\hline 8.38 & 90.40 & 0.43 & 0.06 & $<0.1$ & 0.63 & MG, Brazil & 38 \\
\hline 11.6 & 84.20 & 1.60 & - & - & 2.6 & MG, Brazil & 39 \\
\hline 11.31 & 75.23 & 2.64 & 1.47 & 2.10 & 7.25 & Liaoning, China & 42 \\
\hline 12.31 & 34.72 & 16.22 & 7.63 & 8.92 & 20.2 & Nanjing, China & 43 \\
\hline 15.1 & 84.4 & 0.45 & 0.07 & $<0.1$ & 0 & MG, Brazil & 38 \\
\hline 18.58 & 36.48 & 11.67 & 16.85 & 5.66 & 10.76 & Jiangsu, China & 44 \\
\hline 21.2 & 45.6 & 12.1 & 1.79 & - & 19.31 & China & 45 \\
\hline 21.4 & 65.7 & 0.8 & - & - & 12.1 & MG, Brazil & 46 \\
\hline 21.5 & 71.4 & - & - & - & 7.1 & MG, Brazil & 18 \\
\hline 29.35 & 49.20 & 1.46 & 0.12 & - & 19.87 & MG, Brazil & 34 \\
\hline 32.0 & 46.68 & 3.89 & - & - & 17.43 & MG, Brazil & 47 \\
\hline 35.0 & 63.0 & 1.20 & - & - & 0.8 & MG, Brazil & 48 \\
\hline 38.8 & 14 & 2.01 & 37.5 & 0.36 & 44.83 & China & 45 \\
\hline 42.4 & 47.9 & 5.61 & 0.13 & $<0.1$ & 3.86 & MG, Brazil & 38 \\
\hline 44.52 & 24.40 & 10.95 & 6.20 & 0.99 & 12.94 & Hubei, China & 49 \\
\hline 47.80 & 30.0 & 21.2 & 0.1 & 0.1 & 0.8 & MG, Brazil & 36 \\
\hline 51.37 & 15.11 & 3.39 & 0.23 & 0.16 & 29.74 & MG, Brazil & 13 \\
\hline 55.78 & 16.58 & 15.46 & 1.44 & 0.13 & 10.61 & Joda-Badbil, Orissa, India & 50 \\
\hline 69.21 & 11.42 & 2.38 & 0.49 & 0.11 & 16.39 & Bosnia and Herzegovina & 51 \\
\hline 71.70 & 20.10 & 2.30 & 0.10 & - & 5.8 & MG, Brazil & 52 \\
\hline 73.3 & 8.76 & 1.49 & 3.88 & 0.94 & 11.63 & China & 45 \\
\hline
\end{tabular}

MG: Minas Gerais State.

The fine fraction of the tailings characterized by Pereira et al. ${ }^{52}$ was composed mainly of $\alpha-\mathrm{Fe}_{2} \mathrm{O}_{3}(72 \%)$ and $\mathrm{SiO}_{2}(20 \%)$. A similar result was obtained by Zheng et al. ${ }^{45}$ $\left(73 \% \alpha-\mathrm{Fe}_{2} \mathrm{O}_{3}\right.$ and $\left.9 \% \mathrm{SiO}_{2}\right)$ and Stević et al. ${ }^{51}(69 \%$ $\alpha-\mathrm{Fe}_{2} \mathrm{O}_{3}$ and $11 \% \quad \mathrm{SiO}_{2}$ ). The chemical composition obtained by Augusto et al. ${ }^{46}$ showed that the IOT obtained in the Catas Altas region, Brazil-MG, was composed mainly of $\mathrm{SiO}_{2}(66 \%)$ and total $\mathrm{Fe}(21 \%)$. The tailings from Yeshan Mining Ore Company, Nanjing, China by Duan et al. ${ }^{43}$ also showed a higher amount of $\mathrm{SiO}_{2}(35 \%)$ compared to $\alpha-\mathrm{Fe}_{2} \mathrm{O}_{3}(12 \%)$.

It can be seen that iron oxide, silica, and alumina are the main constituents of iron ore tailings. Some heavy metals such as cadmium, chromium, arsenic, and mercury are in some cases present in very small concentrations or below the limits of detection of quantification. ${ }^{45,53}$ The results obtained by Figueiredo et al. ${ }^{30}$ for a sample of IOT from Doce River after the Fundão Dam collapse showed that this material is classified as nondangerous, noninert, noncorrosive, and nonreactive, according to the classification of the Brazilian standard NBR 10004..$^{54}$

The main crystalline phases detected by $\mathrm{X}$-ray diffraction of iron ore tailings are hematite $\left(\alpha-\mathrm{Fe}_{2} \mathrm{O}_{3}\right)$, goethite $(\alpha-\mathrm{FeOOH})$, and quartz $\left(\mathrm{SiO}_{2}\right){ }^{41,47,55,56} \mathrm{Kaolinite}$ $\left(\mathrm{Si}_{2} \mathrm{Al}_{2} \mathrm{O}_{5}(\mathrm{OH})_{4}\right)$ is a mineral commonly associated with iron ore tailings, ${ }^{41}$ as well as minor gibbsite $\left(\mathrm{Al}(\mathrm{OH})_{3}\right)$. A typical XRD profile showing crystalline phases of quartz, hematite, and goethite is shown in the work published by Silva et al. ${ }^{19}$ The three-dimensional structures of the main phases of iron oxides found in IOT are presented in the Supplementary Information (SI) section (Figure S1 and Table S1).

Mössbauer spectroscopy has also been used to characterize the iron phases present in the fine IOT. ${ }^{19,40,41,46,47}$ A typical Mössbauer spectrum for iron ore tailings of the Quadrilátero Ferrífero region (Brazil-MG) can be found in the work published by Silva et al., ${ }^{19}$ and showed the presence of $\alpha-\mathrm{Fe}_{2} \mathrm{O}_{3}, \alpha-\mathrm{FeOOH}$, and $\mathrm{Fe}_{3} \mathrm{O}_{4}$. Mössbauer parameters, typical of iron ore tailings are presented in Table S2 of the SI section.

Analyses using electron microscopy techniques, e.g., SEM and TEM (scanning and transmission electron microscopies), can bring information about the morphology, roughness, and also about particle size of IOT. The use 
of EDS (energy-dispersive X-ray spectroscopy)/SEM mapping images indicates typically the presence of smaller agglomerated hematite particles on the surface of regular flat large quartz particles. ${ }^{41,47,55}$

Particle size distribution is a relevant parameter that needs to be evaluated. During the extraction of iron ore, fractions of different sizes are generated. Generally, fine tailings show particles smaller than $40 \mu \mathrm{m}$. Coarse sandy tailings generally comprise particles average size of $100 \mu \mathrm{m}$ but with some particles up to $1000 \mu \mathrm{m} .^{48}$ Figure 4 presents information about the size of IOT particles from different works of literature. The data show the heterogeneity of the particle sizes of IOT from different sources. The granulometric analysis of these samples is very important for the study of the application of these materials in different areas.

A typical particle size distribution curve of fine iron ore tailings from the Quadrilátero Ferrífero region (Brazil-MG) is shown in the SI section (Figure S2). The IOT in general have very low surface areas, e.g., $10,{ }^{9} 0.6,3,{ }^{57}<1,{ }^{36,42,50}$, $2,{ }^{46} 6,{ }^{45} 10,{ }^{40} 6 \mathrm{~m}^{2} \mathrm{~g}^{-1} .58,59$

Thermal analysis is an interesting analytical technique that can help to determine the amount of water and hydroxyl groups present in the tailings. Typically, 3 regions of losing weight are observed in a TG (thermogravimetric) curve of these materials. Region $1,\left(25-200{ }^{\circ} \mathrm{C}\right.$, approximately), indicates the loss of mass due to water desorption from the surface of the particles, with an endothermic peak close to $100^{\circ} \mathrm{C}$. In the second region $\left(200-600^{\circ} \mathrm{C}\right)$ dehydroxylation of goethite $(\alpha-\mathrm{FeOOH})$ to hematite $\left(\alpha-\mathrm{Fe}_{2} \mathrm{O}_{3}\right)$ occurs. Structural changes in the quartz phases can also be observed in this region (between 550 and $600{ }^{\circ} \mathrm{C}$ ) due to the

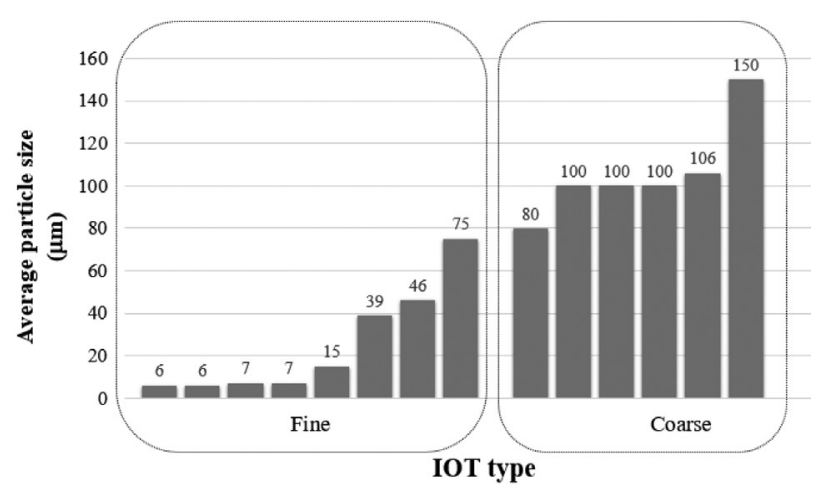

Figure 4. The average particle size of different IOT was obtained by light scattering (laser granulometry). ${ }^{10,34-37,44,48,50,52,60,61}$

structural transition $\alpha \rightarrow \beta$ of the quartz. Above $600^{\circ} \mathrm{C}$, it is possible to observe processes of kaolinite to metakaolinite dehydroxylation, for example. ${ }^{10,62} \mathrm{~A}$ typical TG profile of an IOT of the Quadrilatero Ferrífero region is shown in the work of Silva et al. ${ }^{19}$

\section{Applications for Iron Ore Tailings}

As discussed, IOT is a material extraordinarily rich in silica, iron oxides, and other minority phases. The majority of the applications of IOT (Table 2) can be divided in between the areas of construction and building materials (aggregates for concrete, mortar, Portland cement additives), ceramic industry, ${ }^{35,42,63-65}$ alkali activated materials, ${ }^{56}$ and for technological application, for example, in the synthesis of new materials such as zeolites, mesoporous silica, ${ }^{58,59,66,67}$ and carbon nanotubes, ${ }^{19}$ adsorptions ${ }^{68}$ catalysis,,${ }^{41,46,69}$ batteries ${ }^{51}$ and fuel cell application. ${ }^{70}$

Table 2. Possible applications for iron ore tailings discussed in this work

\begin{tabular}{|c|c|c|c|}
\hline Area & Application & Example & Reference \\
\hline \multirow{4}{*}{ Construction and building materials } & mortar and concrete & use as fine aggregate in concrete & $34,35,42,63-65,71-78$ \\
\hline & geopolymers & use as fine aggregate & $43,56,79,80$ \\
\hline & ceramics & use to produce floors and tiles & $27,38,49,60,71$ \\
\hline & pigments & use as a ceramic pigment & $36,52,81$ \\
\hline \multirow{10}{*}{ Technological application } & silicates & synthesis of zeolites & $58,59,66,67,82$ \\
\hline & iron oxides nanoparticles & synthesis of $\mathrm{Fe}_{3} \mathrm{O}_{4} \mathrm{NPs}$ & 83,84 \\
\hline & \multirow{4}{*}{ catalysis } & catalyst for Fenton and photo-Fenton reactions & $28,45-47,69$ \\
\hline & & catalyst for $\mathrm{CO}$ oxidation reaction & 55 \\
\hline & & catalyst for biodiesel production & 41 \\
\hline & & catalyst for carbon materials synthesis & $19,40,85,86$ \\
\hline & \multirow{3}{*}{ adsorption } & adsorbent for removal of $\mathrm{H}_{2} \mathrm{~S}$ from biogas & 69 \\
\hline & & adsorbent for heavy metals & 87,88 \\
\hline & & adsorbent for phosphate & $89-91$ \\
\hline & battery & synthesis of cathodes & $51,70,92$ \\
\hline
\end{tabular}

NPs: nanoparticles. 
There are two main strategies to use IOT. For the first kind of application, the iron oxide phases are separated from silica by some chemical or physical process, for example, acid or basic leaching. ${ }^{82,83}$ After that, one or both fractions (rich in iron or silicon) can be used for a different kind of application, as shown in Figure 5. The second strategy consists of the direct use of IOT, i.e., without a preliminary separation step. In this work, we will present an overview of the main applications for IOT, before or after the separation step.

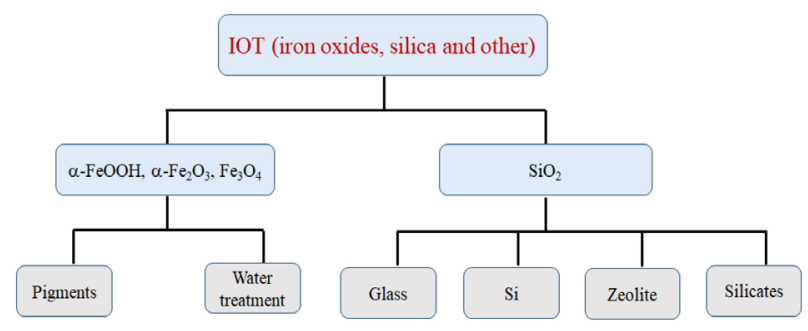

Figure 5. Some possible applications for iron ore tailings (IOT) after the separation step.

\subsection{Construction and building materials}

The use of IOT in the construction industry and building materials is an interesting alternative because of the potentially large volumes of tailings consumed. However, these materials must be used only after a prior characterization of them such as toxicological, mineralogical, granulometry, chemical, and technological specific tests. ${ }^{73}$ Some of these applications are in the production of brick, concrete, mortar, ceramics, alkali activated materials and pigments. ${ }^{78}$

Some interesting examples of IOT use in the construction and building area are the model houses built by a collaboration of UFMG with the mining companies Samarco $^{93}$ and $\mathrm{Gerdau}^{94}$ that used all the materials based on mining tailings (Figure 6).

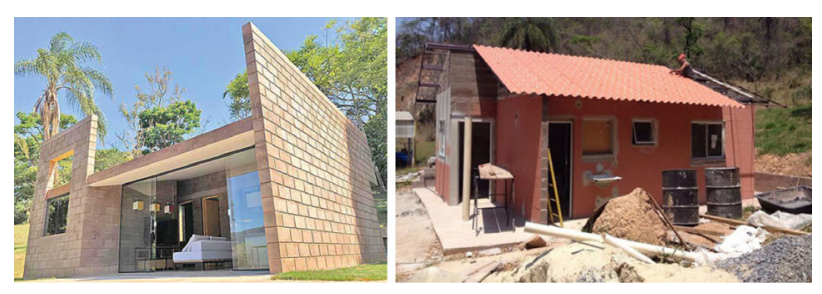

Figure 6. Model houses built using IOT in collaboration projects of UFMG with the mining companies Samarco and Gerdau..$^{93,94}$

Another important initiative, in 2020, was the installation of a small industrial unity to produce different items for construction and building using IOT in Itabitirto, MG-Brazil by the Vale company. The cost to process 30.000 tons per year of IOT is approximately US\$ 5 million. ${ }^{95}$

\subsubsection{Mortar and concrete}

Concrete is generally made up of coarse and fine aggregate. The tailings are used for total or partial replacement of the fine aggregate. IOT can be used as fine aggregates as they are inert and the particle size of the tailings is significantly larger than that of cement. ${ }^{76}$ IOT is a particularly thin material (more than $50 \%$ of the material has a particle size of fewer than $75 \mu \mathrm{m}$ ). It is worth mentioning that in Brazil approximately 100 million tons of mortar are consumed per year, and 184 million tons of iron ore tailings are generated annually. ${ }^{35}$

Sandy iron ore tailing ${ }^{34}$ can be used to make concrete in place of natural sand, but this substitution is limited due to the fine granulometry. For example, the compressive strength of interlocked blocks obtained with the use of cement and the sandy residue is at most $18 \mathrm{MPa}$. It should be noted that the minimum resistance value stipulated by the standard (NBR 9781) for pavements for light traffic is $35 \mathrm{MPa} .^{77}$

The physical properties of the tailings have a significant impact on the workability, density, dimensional stability, strength, and durability of the concrete. ${ }^{78}$ The replacement of fine aggregates by IOT is technically feasible, as this substitution can improve the mechanical properties of the material, for example. ${ }^{35,42,63-65,71-73,76}$

Generally, workability is an important property of fresh mortar or concrete mixtures. Some studies ${ }^{73,74,76,78}$ show that the flow of mortar decreased with increasing tailing amount. These changes are related to the particle size distribution of IOT. Finer particles increased the total specific surface area of fine aggregates. This might be attributed to particle size and surface texture of tailings, which may demand more water and hence reduce the workability. ${ }^{74}$

According to a very interesting review ${ }^{74}$ about the use of tailings in cement and concrete, the physical properties of tailings influence directly the durability of the concrete. Some studies showed that the water permeability increased with the addition of more than $10 \%$ of tailings in the concrete. ${ }^{74}$ On the other hand, Sunil et al. ${ }^{75}$ in a work using $35 \%$ of IOT and $20 \%$ of fly ash produced concrete with very good durability properties (sulfate attack of $0.20 \%$ and water absorption of $0.76 \%$ ).

Mortar hardening time increases when IOT is incorporated into cement or mortar. This is associated with the presence of some heavy metals. They delay the hydration of the cement, forming a low permeability layer around the unhydrated grains. Other properties affected by the addition of IOT are the density and absorption of water (physical property related to porosity). Porosity is also an altered characteristic. ${ }^{74}$

The use of IOT in mortar and concrete is not feasible when the substitution is greater than $20 \%$. This can 
be attributed to greater water absorption by the mortar modified with mining tailings in relation to conventional mortar. ${ }^{35}$ However, some studies ${ }^{48}$ show that the use of IOT causes less water absorption, less porosity, and less surface wear than mortar produced with natural aggregates. These results are generally attributed to the filling of the pores of the material by the tailing which is generally very fine. ${ }^{48}$

The compressive strength of mortar prepared with IOT improves, and this is usually associated with the size of the particles that improve the pore structure. This increase in resistance presents a limit to the amount of IOT that can vary according to the characteristics of the IOT used. ${ }^{42,65}$

IOT with high $\mathrm{SiO}_{2}$ content can be used in preparing concrete to replace cement, according to results presented by Cheng et al., ${ }^{42,65}$ The results of these authors showed that the amount of IOT used can affect the durability of the concrete and the increase in the rate of replacement of tailings in cement tends to decrease the compressive strength of concrete.

In general, we can summarize that the use of IOT as a fine aggregate leads to an increase in the compressive strength and this can be associated with the size of the particles (usually fine) that can fill the mortar pores. By comparison, at the same workability, the compressive strength decreased, for the tailings need more water. Hence, considering the compressive strength and the workability of mortar and concrete, it is generally recommended to adopt no more than $30 \%$ tailings substitution as fine aggregate. ${ }^{74,76}$ In general, the works that use IOT in concrete and mortar applied the fractions that are richer in silica compared to the iron content.

Regarding durability, the use of IOT has a different effect. Some studies showed that the penetration of chloride ions in the concrete made with tailings declined with the increase in tailings content. The results showed that the concrete incorporating tailings enhanced the chloride penetration resistance compared to the control specimens. ${ }^{74}$

\subsubsection{Alkaline activated material and geopolymers}

Alkali-activated materials and geopolymers are inorganic materials produced by the alkaline activation of aluminosilicates. The synthesis involves the use of a concentrated solution of alkaline hydroxide and silicate. The resulting compound has a very stable inorganic polymeric structure, amorphous or semi-crystalline with interconnected $\mathrm{Si}-\mathrm{O}-\mathrm{Al}-\mathrm{O}-\mathrm{Si}$ bonds. Alkaline activated material has physical-chemical properties similar to those of Portland cement with considerable advantages such as superior durability, resistance to sulfate, resistance to acid, and resistance to fire. ${ }^{56}$ According to some studies is possible to use IOT for the production of these materials. ${ }^{43,56,79}$ Some studies ${ }^{43}$ showed that alkali-activated materials can be prepared with fly ash and IOT and that the porosity of the material increases with the amount of IOT added. However, the addition must be less than $40 \%$. In this case, the alkali-activated material obtained showed a wide distribution of pore diameter ( 3 to $40.000 \mathrm{~nm}$ ) concentrated between 10-110 nm.

For the production of geopolymers (Figure 7), the characterization of the tailings must be carried out to determine the amount of silica and alumina in their composition. This is necessary since the synthesis of these structures generally requires a $\mathrm{Si} / \mathrm{Al}$ ratio between 3.2 and $4.5 .^{80}$

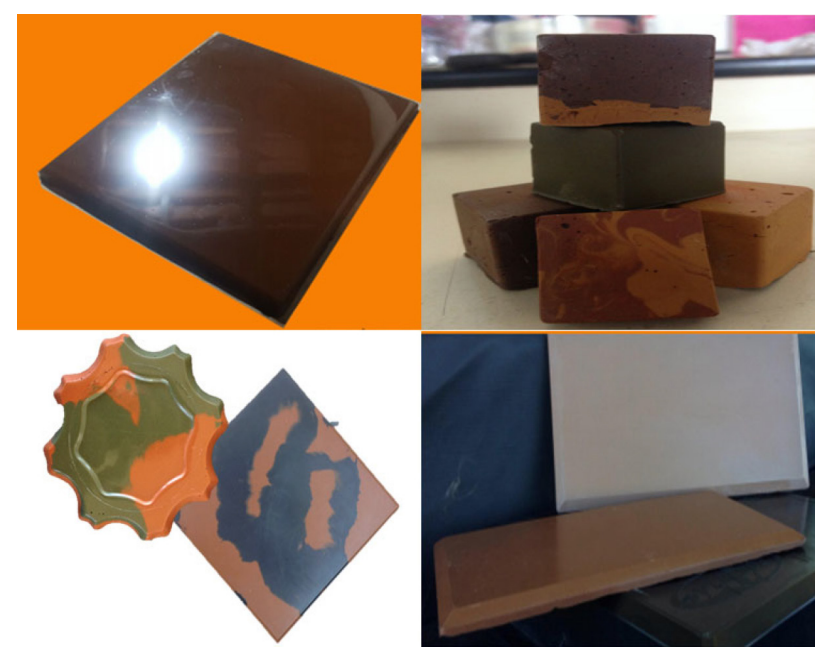

Figure 7. Geopolymer products obtained by GEEGO startup using IOT.

Defáveri et al.$^{56}$ synthesized geopolymers using tailings with high amounts of silica and iron and low amounts of $\mathrm{Al}_{2} \mathrm{O}_{3}$. IOT has a silicon/aluminum ratio ( $\mathrm{Si} / \mathrm{Al}$ ) of 4.59. The obtained material showed high resistance to compression and flexion, reaching values above $100 \mathrm{MPa}$ for resistance to compression and $20 \mathrm{MPa}$ for resistance to flexion. SEM images showed structures with low porosity and XRD showed zeolite phases present in the geopolymer structure formed. A very interesting initiative in the area of geopolymer production is the startup GEEGO. This startup was created in 2019 and develops different geopolymer products using iron ore tailings in its composition. Figure 7 presents some geopolymeric structures produced by this startup. For geopolymers synthesis is more interesting the use of IOT rich in silica.

\subsubsection{Ceramics}

IOT has particle size and shape that allow their use in the ceramics industry, so it is one of the technological applications that stands out. The clays used for the manufacture of ceramics normally consist of hydrated 
aluminum silicates with high levels of $\mathrm{SiO}_{2}$ and $\mathrm{Al}_{2} \mathrm{O}_{3}$ and low levels of iron. Some iron ore tailings have these characteristics. $^{38}$

The use of IOT with low particle size is an excellent alternative for the production of floors and tiles. Ceramic materials with IOT in their composition generally present a higher porosity (about $42.5 \%$ ) when compared to pure ceramic $(25.6 \%)$. The addition of IOT also increases strength, but decreases density and water absorption, most likely due to possible hydrophobic behavior of the tailings. ${ }^{38}$

The use of iron ore tailings with a high concentration of silica can be advantageous when the objective is to produce ceramic tiles. In this case, the maximum allowed amount of IOT in the composition cannot be greater than $40 \%$ so that physical properties such as hardness and resistance to scratches are the same or even better compared to ceramic produced without IOT. ${ }^{60}$

For the production of porcelain tiles with incorporated IOT, the firing temperature and the proportion of tailings significantly influence the properties of the final product. The increase in temperature improves densification and other physical properties. However, when the amount of tailings used is large, the sintering temperature range decreases. Considering industrial production, the recommended amount of tailings addition is between 55$65 \%$ by weight, together with $25 \%$ by weight of kaolin and about $10-20 \%$ by weight of $\mathrm{SiO}_{2}$. The proper sintering temperature is $1200^{\circ} \mathrm{C} .{ }^{49}$

Bricks with $20.94 \%$ of water absorption and resistance to compression equal to $4.27 \mathrm{MPa}$ were obtained using iron ore tailings with high silica content. The addition of the IOT contributed to reduce firing linear shrinkage and compressive strength, and increase bulk density, water absorption, and apparent porosity. The best samples contained $29.1 \%$ (by mass) of IOT. This amount of waste met the international standards required for the manufacture of bricks. ${ }^{71}$ For ceramic applications it is interesting the use of IOT with high levels of $\mathrm{Si}$ and $\mathrm{Al}$ and low content of iron oxides.

\subsubsection{Pigments}

Pigments are defined as compounds, usually calcined, formed by colored metal oxides which, when mixed with enamel or a mass, form a colored ceramic. Their stability depends on their crystalline structure or mineral composition. ${ }^{36,52}$

Numerous factors must be taken into account when selecting a pigment for a specific application. Among these, chemical stability stands out. The pigments used to color the ceramic paste must be stable at temperatures above $1200{ }^{\circ} \mathrm{C} .{ }^{36,52}$
The importance of iron oxide pigments is also based on their non-toxicity, chemical stability, durability, variety of colors, and, particularly, their low cost for emerging markets in growing concern with the use of heavy metals used in the production of pigments. ${ }^{81}$ The use of IOT as a pigment allows the cost of colored ceramics to be reduced because of their low commercial value.

According to Pereira et al., ${ }^{52}$ IOT can be used as a ceramic pigment since the waste is thermally stable at 500 to $1100{ }^{\circ} \mathrm{C}$, that is, it does not present a reaction that may interfere with the firing process. Furthermore, according to the authors, the addition of IOT in transparent glassy ceramics does not cause a significant color change. However, in white and matte glassy ceramics there are major changes in the color and shade of the enamel as the treatment temperature increases. Another interesting observation is that the addition of IOT caused changes in the glass transition temperatures, decreasing the softening and melting temperatures of the transparent and matte ceramics and increasing these characteristic temperatures for the white ceramics. For this application is important the use of IOT rich in iron oxides.

\subsection{Technological application}

\subsubsection{Synthesis of silicates}

A remarkably interesting application for sandy iron ore tailing is in the synthesis of porous materials.

Generally, tailings with high silica content are the most used for this purpose. Most tailings have silica with the same basic structural unit, with oxygen and silicon tetrahedron connected to other atoms, such as $\mathrm{Zn}$ and $\mathrm{Mg} .{ }^{58,59} \mathrm{The}$ viability for the preparation of porous silicates is even greater for tailings with a high silica content $(>70 \%) .{ }^{59}$ Besides, as silica tetrahedrons are highly sensitive to the presence of alkaline hydroxides, consequently, tailings are also. In this way, it is possible to explore the tailings from iron mining as a secondary resource to build porous materials with high added value. ${ }^{58}$

The $\mathrm{SiO}_{2}$ recovered and purified from these wastes is used for the preparation of porous silica micro/mesoporous and zeolites, interesting material for uses related to energy storage and environmental protection. ${ }^{59,66,67,82}$ Zhang et al.$^{82}$ obtained structures of the type ZSM-5, from iron ore tailings (IOTs), with well-defined microporous and mesoporous structures, and with a large surface area and high acid strength. The Brunauer-Emmett-Teller (BET) surface area of the synthesized materials varied from 303 to $344 \mathrm{~m}^{2} \mathrm{~g}^{-1}$. The mesopore volume and average pore width of zeolite of type HZSM- 5 were $0.039 \mathrm{~cm}^{3} \mathrm{~g}^{-1}$ and $0.78 \mathrm{~nm}$, respectively. The total acidity of the samples studied by temperature 
measurement of desorption of ammonia ( $\mathrm{NH}_{3}$-TPD) indicated that the material presented two types of acidic sites: weak (at 195 and $191{ }^{\circ} \mathrm{C}$ ) and strong (at 394 and $362^{\circ} \mathrm{C}$ ). For this application it is better to use IOT rich in silica.

\subsubsection{Iron oxides nanoparticles synthesis}

Another type of interesting structure obtained from the IOT is iron oxide nanoparticles (such as magnetite, $\mathrm{Fe}_{3} \mathrm{O}_{4}$ ). Conventional routes for the synthesis of $\mathrm{Fe}_{3} \mathrm{O}_{4}$ include mainly ball milling, thermal decomposition, chemical precipitation, and sonochemical methods in which chemicals of high purity are used as a source of iron. The use of these reagents can limit the application of these magnetic nanoparticles in many potential areas, including wastewater treatment processes. The use of iron-based solid/liquid waste is still challenging and limited efforts have been dedicated to date..$^{83,84}$

Wu et $a l .^{83}$ developed a method for the preparation of $\mathrm{Fe}_{3} \mathrm{O}_{4}$ from tailings, by ultrasound-assisted chemical coprecipitation using high-purity iron separated from iron ore tailings by the acid leaching method. $\mathrm{Fe}_{3} \mathrm{O}_{4}$ nanoparticles with $15 \mathrm{~nm}$ in diameter exhibited superparamagnetic behavior. A similar procedure was carried out by Giri et al.$^{84}$ The obtained magnetic nanoparticles showed superparamagnetic behavior and good dispersibility in an aqueous medium with high stability. The micrographs (SEM and TEM) showed that the synthesized particles had spherical and/or cubic shapes ranging in size from 8.3 to $23.0 \mathrm{~nm}$. In this case, is interesting the use wastes rich in iron oxide phases.

\subsubsection{Catalysis}

Most applications of IOT in catalytic processes involve the use of these wastes in chemically modified forms. In these modifications, an attempt is usually made to increase the number of active catalytic sites that promote chemical reactions. Some examples are described as follow:

\subsubsection{Catalyst for Fenton and photo-Fenton reactions}

A promising application of iron ore tailings is as a catalyst, for example, in the treatment of effluents by advanced oxidative processes. This is because iron oxides are efficient catalysts for Fenton and photo-Fenton reactions. ${ }^{28,46,47,69}$ The main iron oxides phases presented in IOT are hematite and goethite, which makes these tailings promising candidates for Fenton reaction. The advanced oxidative processes represent a set of technologies based on the generation in situ, of hydroxyl radicals $\left({ }^{\circ} \mathrm{OH}\right)$, hydroperoxyl $\left({ }^{\circ} \mathrm{OOH}\right)$, and species of active oxygen $\left(\mathrm{O}_{2}\right)$, which are capable of degrading various organic compounds. ${ }^{47,69}$

The efficiency of these processes is greater when the iron is in the state of oxidation $2+\left(\mathrm{Fe}^{2+}\right)$. However, the most common oxidation state in iron tailings is $\mathrm{Fe}^{3+}$. The presence of $\mathrm{Fe}^{3+}$ does not prevent the use of tailings as a catalyst, but it does modify the rate of degradation of the organic molecule. ${ }^{47,69}$

de Freitas et $a l .{ }^{47}$ used tailings from iron mining, containing $\mathrm{SiO}_{2}(46.8 \%), \mathrm{Fe}(32.0 \%)$, and $\mathrm{Al}_{2} \mathrm{O}_{3}(3.89 \%)$ as main minerals, in Fenton type reactions for the oxidation of the methylene blue molecule. For this, the IOT was calcined at $550{ }^{\circ} \mathrm{C}$ in air, for $2 \mathrm{~h}$ and presented an interesting catalytic activity (removal of approximately $75 \%$ of the dye). The authors also showed that the activity can be improved with the activation of the catalyst surface by hydrogen gas, promoting the reduction of $\mathrm{Fe}^{3+}$ type sites to $\mathrm{Fe}^{2+}$ according to the equations below. The authors evaluated the reduction profile by programmed temperature reduction $\left(\mathrm{TPR}-\mathrm{H}_{2(\mathrm{~g})}\right.$ ). A first peak was observed at $514{ }^{\circ} \mathrm{C}$, attributed to the transition of the phases from $\alpha-\mathrm{Fe}_{2} \mathrm{O}_{3}$ to $\mathrm{Fe}_{3} \mathrm{O}_{4}$ (equation 1). The second reduction $\left(\mathrm{Fe}_{3} \mathrm{O}_{4}\right.$ to $\mathrm{FeO}$ (equation 2)) occurred between 600 and $850{ }^{\circ} \mathrm{C}$ with a maximum of $755{ }^{\circ} \mathrm{C}$. In this region, the transition from $\mathrm{FeO}$ to $\mathrm{Fe}^{0}$ also occurs (equation 3 ).

$3 \alpha-\mathrm{Fe}_{2} \mathrm{O}_{3(\mathrm{~s})}+\mathrm{H}_{2(\mathrm{~g})} \rightarrow 2 \mathrm{Fe}_{3} \mathrm{O}_{4(\mathrm{~s})}+\mathrm{H}_{2} \mathrm{O}_{(\mathrm{g})}$
$\mathrm{Fe}_{3} \mathrm{O}_{4(\mathrm{~s})}+\mathrm{H}_{2(\mathrm{~g})} \rightarrow 3 \mathrm{FeO}_{(\mathrm{s})}+\mathrm{H}_{2} \mathrm{O}_{(\mathrm{g})}$
$\mathrm{FeO}_{(\mathrm{s})}+\mathrm{H}_{2(\mathrm{~g})} \rightarrow \mathrm{Fe}_{(\mathrm{s})}^{0}+\mathrm{H}_{2} \mathrm{O}_{(\mathrm{g})}$

Natural or modified iron ore tailings in a $\mathrm{CH}_{4}$ reducing atmosphere at $600{ }^{\circ} \mathrm{C}$ or impregnated with residues of polyethylene terephthalate (PET) powder (from bottle recycling) and treated under an inert atmosphere of $\mathrm{N}_{2}$ at $600{ }^{\circ} \mathrm{C}$ were used as heterogeneous catalysts for the Fenton reaction. This tailing was composed of $\mathrm{SiO}_{2}$, hematite $\left(\alpha-\mathrm{Fe}_{2} \mathrm{O}_{3}\right)$, and goethite $(\alpha-\mathrm{FeOOH})$. The $\mathrm{CH}_{4}$ modified catalyst showed reduced iron phases (mainly $\mathrm{FeO}$ ). The material prepared together with PET, on the other hand, consists of carbon islands dispersed over an iron oxide matrix. A partial reduction of iron $\left(\mathrm{Fe}^{3+} \rightarrow \mathrm{Fe}^{2+}\right)$ occurred during the thermal decomposition of PET, forming magnetite $\left(\mathrm{Fe}_{3} \mathrm{O}_{4}\right)$. The authors ${ }^{46}$ showed that the catalytic activity of the tailings is improved when it undergoes treatment in a reducing atmosphere with $\mathrm{CH}_{4}$ because of the formation of reduced iron species $\left(\mathrm{Fe}^{2+}\right)$. The composites made from PET bottles were very active for removing contaminants from water through combined mechanisms of adsorption and oxidation. ${ }^{46}$ In this study, the potential of these catalysts was tested in the oxidation of acetaminophen molecule and Methylene Blue dye (MB) and Rhodamine B (RhB) dye.

IOT has also been used effectively for the degradation of the azo dye molecule, Acid Orange $7 .{ }^{45}$ In this work, it was observed that the degradation of the dye can be correlated 
with the content of iron oxide and cupric oxide in IOT, for example. The authors conclude that the coexistence of metallic elements, particularly $\mathrm{Cu}$, can accelerate the heterogeneous reaction of the Fenton type.

An interesting application of iron waste is in the treatment of aqueous effluents generated in the process of processing the ore. The iron compounds present in the tailings can act as a catalyst for reactions of the Fenton and photo-Fenton type in the degradation/removal of surfactants used in these processes. ${ }^{28}$

\subsubsection{Catalyst for $\mathrm{CO}$ oxidation reactions}

Iron tailings were used in the preparation of iron oxide-hydroxide $(\alpha-\mathrm{FeOOH})$ and used as a support for gold nanoparticles for $\mathrm{CO}$ oxidation reactions. The used iron ore has low iron content $(40 \%), 42 \%$ of $\mathrm{SiO}_{2}$, and about $1 \%$ of $\mathrm{Al}_{2} \mathrm{O}_{3}$. To prepare $\alpha-\mathrm{FeOOH}$, the IOT went through acid digestion leading to complete leaching of the hematite. The leached iron portion was used to prepare the iron oxide-hydroxide support. The authors concluded that the catalytic activity of the compound is greater when used without any pretreatment, becoming inactive when pretreated at $300{ }^{\circ} \mathrm{C} .{ }^{55}$

\subsubsection{Catalyst for biodiesel production}

In addition to oxidative reactions, mining tailings were also used as supports for sulfate-like acid groups and were applied as catalysts in oleic acid esterification reactions for the production of biodiesel. ${ }^{41}$ The authors used $\left(\mathrm{NH}_{4}\right)_{2} \mathrm{SO}_{4}$ and $\mathrm{H}_{2} \mathrm{SO}_{4}$ as sulfate group sources. The main mineral phases in this tailing were hematite and quartz. The authors observed that the most efficient methodology for generating sulfated oxides, in this case, involved the use of sulfuric acid $\left(0.1211 \mathrm{mmol} \mathrm{g}^{-1}\right)$. In this case, the number of acidic groups that are necessary for the reaction to occur was greater. Conversions close to $100 \%$ oleic acid to methyl oleate were obtained.

\subsubsection{Catalyst for carbon materials synthesis}

Another very interesting application for iron ore tailings is for carbon nanotubes synthesis. ${ }^{19,85,86}$ The iron present in the tailings, after a reduction process, acts as a catalyst for the synthesis through a process called chemical vapor deposition (CVD). In this process, molecules such as acetonitrile, ethylene, methane, carbon dioxide, and ethanol are used as carbon sources and the catalyst acts in the decomposition of this source and the structuring of carbon nanotubes. ${ }^{19}$

Silva et al. ${ }^{19}$ used IOT for the carbon nanotubes synthesis. The tailings analysis indicated the presence of $44 \%$ of iron. Four materials were obtained and presented morphology and structure comparable to other nanotubes described in the literature. The formation multi-walled carbon nanotubes was observed for all synthesized materials.

The potential of iron mining residues rich in $\alpha-\mathrm{Fe}_{2} \mathrm{O}_{3}$ and $\alpha-\mathrm{FeOOH}$ was tested for the development of composites based on graphitic carbon nitride. Composites with promising characteristics, such as greater specific surface area and magnetic behavior due to the formation of maghemite, were used as catalysts for the emerging contaminant acetaminophen, commonly known as paracetamol. The IOT used in this work had an average particle size of $7.4 \mu \mathrm{m}$ and, therefore, is considered an ultrafine powder with a high content of iron oxides (approximately $75 \%$ by mass). ${ }^{40}$

\subsubsection{Adsorption}

IOT can also be used as an adsorbent, either without any prior modification or after some chemical treatment. These changes seek to improve the capacity of the tailings to adsorb the most different types of pollutants, whether organic or inorganic.

\subsubsection{Adsorbent for removal of $\mathrm{H}_{2} \mathrm{~S}$ from biogas}

In technologies involving adsorption, iron tailings were used, for example, in the purification of biogas, aiming to adsorb $\mathrm{H}_{2} \mathrm{~S}$. This application is interesting from a scientific and technological point of view, since the iron oxides obtained from acid mining drainage are potential adsorbents for desulfurization, due to their low cost and good adsorption performance. The authors concluded that the chemical, physical and morphological analyzes of the tailings, and the adsorbents obtained from them, are essential to understand and interpret the experimental data. ${ }^{68}$

\subsubsection{Adsorbent for heavy metals}

An interesting application for IOT is related to processes involving the adsorption of heavy metals such as arsenic ${ }^{87}$ and lead. ${ }^{88}$ The issue involving arsenic adsorption is that iron compounds (iron oxides, oxyhydroxides, and hydroxides, including goethite $(\alpha-\mathrm{FeOOH})$ and hematite $\left(\alpha-\mathrm{Fe}_{2} \mathrm{O}_{3}\right)$, etc.) for this purpose only present high adsorption capacity at low $\mathrm{pH}$. An interesting way for the activation of the iron oxide surfaces to improve the adsorption capacity is the treatment with $\mathrm{NaOH}$ in the liquid phase. This method activates iron oxide/hydroxide compounds and generates new reactive functional hydroxyl groups on the surface, which provide an increase in the ion exchange process. ${ }^{87}$ Yuan et al. ${ }^{88}$ also concluded that the removal of $\mathrm{Pb}^{2+}$ is strongly influenced by the $\mathrm{pH}$ of the medium. However, for the removal of this metal, a pH close to 6 was the most suitable for adsorption. 


\subsubsection{Adsorbent for phosphate $\left(\mathrm{PO}_{4}{ }^{3-}\right)$}

Phosphate is an important plant nutrient widely used in the production of fertilizers. Therefore, its recovery is important since the demand for phosphate rocks is increasing and some studies ${ }^{96}$ predict exhaustion of these rocks in the next 50-100 years. Iron oxide, derived from IOT, can easily and efficiently adsorb and recover this anion. Some works ${ }^{89,90}$ showed that the iron phases present in the material and the amounts of $\mathrm{OH}^{-}$groups are important factors that must be taken into account in the adsorption process. Hematite is not a good phosphate adsorbent, probably because it does not contain the $\mathrm{OH}^{-}$groups important for the adsorption process. However, when the IOT is treated with hydrochloric acid, the iron oxides are solubilized. With re-precipitation, the $\mathrm{OH}^{-}$groups become available, which causes the adsorption to increase.

A very interesting study involving iron ore tailings was developed by Suh et al. ${ }^{91}$ The researchers produced a nanoadsorbent capable of removing phosphorus and nitrogen from wastewater. The work showed that the material resulting from the adsorption can be used as a controlled release fertilizer since the phosphorus and nitrogen impregnated on the adsorbent could be released slowly in the soil. This type of material would be an excellent lowcost fertilizer.

\subsubsection{Battery}

An interesting work involving the synthesis of $\mathrm{LiFePO}_{4} / \mathrm{C}$ cathodes was developed by Wang et al. ${ }^{92} \mathrm{In}$ this study $\mathrm{FePO}_{4}$, used as a precursor to $\mathrm{LiFePO}_{4} / \mathrm{C}$, was prepared by leaching IOT with concentrated sulfuric acid, phosphoric acid, and hydrogen peroxide. The effects of $\mathrm{FePO}_{4}$ obtained from iron tailings under different $\mathrm{pH}$ conditions on the final structure of $\mathrm{LiFePO}_{4} / \mathrm{C}$ were evaluated, focusing on morphology and electrochemical performance.

Some studies ${ }^{70}$ mention the use of iron tailings as an anodic catalyst for the generation of energy in microbial fuel cells. The use of tailings may produce cheap and effective catalysts for applications in bioelectrochemistry. For this application, tailings with a greater number of ferrous compounds produce more important catalytic reactions in cells, since the presence of these compounds can improve electron transfer. ${ }^{70}$

Hematite core nanoparticles with carbon shells were produced using iron from the mining industry. The material obtained can be used in the production of lithium-ion batteries. ${ }^{51}$ This technology is interesting because the iron obtained from IOT makes the process more economical since iron solutions are obtained by the simple process of acid digestion of mining waste.

\section{Technical Aspects of IOT Utilization}

Although many possible applications for IOT are presented in the literature, there are still important technical and economic aspects that must be considered about the use of these materials. For a better understanding of these aspects, the following are the results of a search in the state of the art, about the use of iron ore tailings, highlighting the type of application and those responsible for the patent deposits. Finally, some factors that still limit the use of large-scale mining tailings will be discussed.

\subsection{Analysis of the patents related to iron ore tailings}

The literature presents several patent filing banks that have used iron ore tailings for various technological applications. The patents described hereon were mapped on the website of the National Institute of Industrial Property (INPI), Brazil, Worldwide-Spacenet and Google Patents, United States Patent and Trading Office (USTPO), Canadian Intellectual Property Office (CIPO) and Australia Patent Office (APO). The following keywords were used: "mining waste", "iron waste", "iron mud waste", "iron oxide + waste", "iron mining", "iron ore tailings".

The search found 95 patent applications on the selected database, which are grouped as applications for iron ore tailings and patent filing agents (Figure 8).

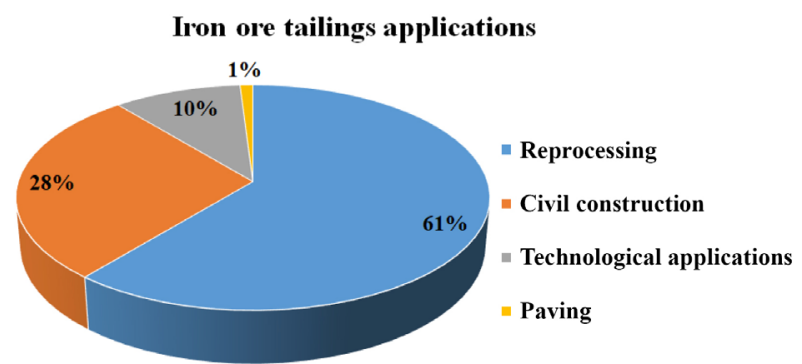

Figure 8. Applications related to iron ore tailings, identified from queries on the INPI, Worldwide Spacenet, USTPO, CIPO, and APO websites.

It can be observed that most of the patent applications filed for the use of iron ore tailings are related to reprocessing of the material to recover the iron present in the iron ore tailings. This application accounts for $61 \%$ of the patents found in this study. Other applications for iron ore tailings are related to using in civil construction (28\%), 10\% related to technological applications such as binders, catalysts, polymers, production of silicon carbide, nanofibers, and sodium silicate, obtaining ferric chloride, and $1 \%$ related to road paving.

It is interesting to observe that non-mining companies are the main responsible for filing patents related to the 
use of iron ore tailings, followed by inventors, mining companies, universities, universities and companies, universities and research centers, mining companies and universities, and governments (Figure 9).

\section{Institutions responsible for patents}
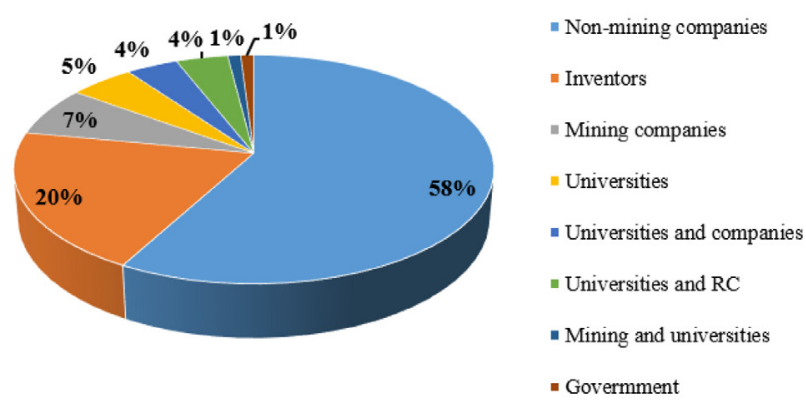

Figure 9. Institutions responsible for patent deposits related to the use of iron ore tailings. The graphic was based on queries to the INPI, Worldwide Spacenet, USTPO, CIPO, and APO websites.

\subsection{Limiting factors for the use of iron ore tailings}

Although IOT represents a serious concern due to storage cost and many other problems, very few initiatives have been effectively implemented to obtain products from this material. On the other hand, there are in the scientific and patent literature a wide variety of possibilities to transform IOT into products for different applications. In this context, is of great importance to understand the bottlenecks to extensively use these technologies. A preliminary simple analysis is presented here to understand the main factors that hinder the industrial and commercial use of IOT. These barriers can be classified as technological and market barriers (Figure 10).

Technical barriers start with the development of research towards the application of IOT. Although there is a large number of published papers, most of these works are still in a very preliminary lab stage without any consideration of technical and economic feasibility.

After this more basic research, detailed work is necessary to evaluate the proposed technology concerning the following main questions: the developed product was tested with a client and performed well? Does the product have a clear market and differentials compared to competitors? Can it be produced industrially? Any concern related to logistic or legal/licensing limitations? Most of these questions can be answered by scaling up the technology, i.e., build a pilot plant to produce, from hundreds to thousands of $\mathrm{kg}$, to carry out tests with real clients (POC, proof of concept). From the pilot plant, besides the development of the product, it is also developed the industrial process and obtained all the variables important to determine the economic and technical feasibility of the process. After most of these issues are addressed, the technology reaches a maturity level to go to market. At this point start the market barriers. Some of these market barriers are briefly discussed below.

The scale of the generation of iron ore tailings is possibly the most important concern. No single application will be enough to give a destination to the huge amount of IOT generated by a mining company. Therefore, it is mandatory to develop a large number of applications. Another aspect is that in mining countries other productive chains, such as those in civil construction, are already structured and have companies that supply raw materials. The introduction of mining waste on large scale as raw material could cause a breakdown in the supply chain, generating other negative economic and social impacts, which must be taken into account for their great relevance.

Logistic issues are a very strong limitation. The distance between consumer markets must also be taken into account one of the characteristics of the mining activity is locational rigidity, in general in regions far from traditional production centers. In this way, the logistical system for transporting iron ore tailings from mines to possible consumption markets is of great importance. Due to the produced volumes, the transportation of this material will impact roads and highways, causing environmental impacts such as the emission of polluting gases and the generation of noise and particulate emissions. Also, the price of this
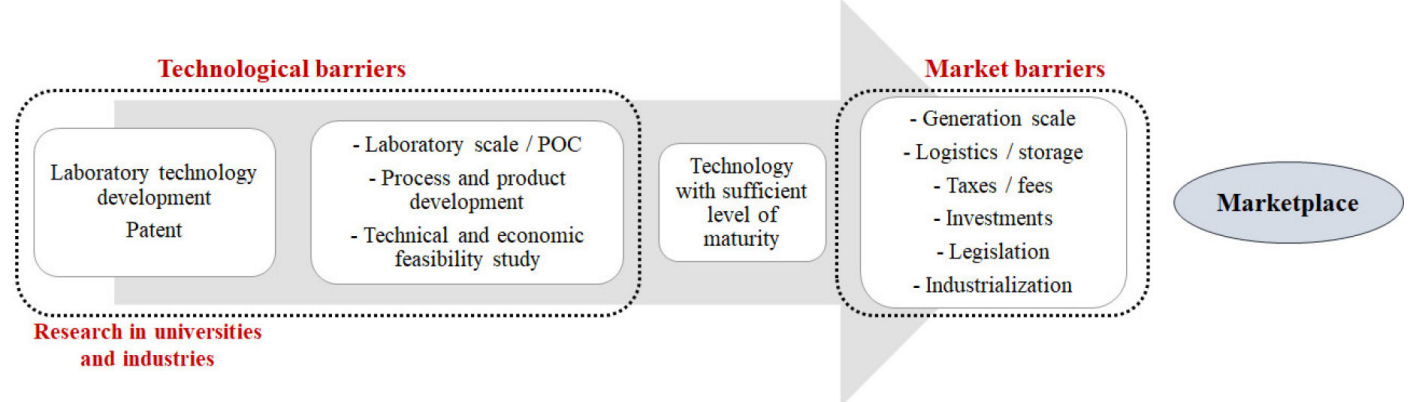

Figure 10. Diagram of technological and market barriers developed for iron ore tailings (adapted from da Gama et al. ${ }^{97}$ ). 
transport will have a strong impact, and may even surpass the commercial value of the iron ore tailings.

Once transported, these IOT must be handled and stored by the production chain that will use them as raw materials; to this end, availability of physical space, equipment, and labor will be necessary for its use. As the production chains are already arranged, the consumer market will want to receive only the necessary amount of material for its direct use, already within its technical specifications. This means that the iron ore tailings must be treated inside mining operations, and then send to consumer markets.

Consumer markets have technical regulations, or standards, that determine what characteristics are required for the raw materials that will be used in the production chain. Therefore, a standard should be created for the use of iron ore tailings, so they can follow universal technical specifications.

The taxes and duties that will be applied to iron ore tailings will also have a major impact on the pricing of these products, for use as second-generation raw materials. If there is any type of tax incentive to take advantage of the iron ore tailings, they may take the market currently served by nonmetallic mining companies of primary mineral goods such as sand and gravel, which can eventually be characterized as unfair competition.

\section{Conclusions}

Iron mining is an extremely important economic activity in many countries. On the other hand, the large volume of tailings generated, IOTs, is a huge problem for the mining companies, governments, and main populations around the mines due to storage in damns and the risk of accidents. The development of processes to convert IOT into products with added value is of great importance. The scientific literature and patent databases showed many potential applications have been developed such as those related to civil construction (aggregates for concrete, mortar, Portland cement additives), ceramic industry, alkali activated material and geopolymer, synthesis of new materials such as zeolites, mesoporous silica, carbon nanotubes adsorption, catalysis, batteries, and fuel. On the other hand, the actual use of these applications on an industrial and commercial scale has been scarce due to several technological and market barriers. IOT should be regarded as a raw material with many potential uses which will be very important in a second mining cycle in the near future. In Brazil, mining companies cannot store IOT in dams since 2020 due to federal law (number 14066, enacted on September 30, 2020).${ }^{98}$ Currently, mining companies are using press filtration to produce IOT piles for safe storage.

\section{Supplementary Information}

Supplementary information is available free of charge at http://jbcs.sbq.org.br as PDF file.

\section{Acknowledgments}

The authors acknowledge CNPQ (PDJ process number 150179/2018-9 (S. S. Vieira)), CAPES (PNPD, process number 88887.363108/2019-00 (S. S. Vieira)), INCT Midas (project number 465594/2014-0), and FAPEMIG (Rede Candonga e Rede Plataforma) for financial support.

\section{Author Contributions}

Ottávio R. Carmignano was responsible for conceptualization, data curation (equal), investigation (equal); Sara S. Vieira for conceptualization (lead), data curation (lead), formal analysis (lead), investigation (lead), methodology (lead), visualization (lead), writingoriginal draft (lead), writing-review and editing (lead); Ana Paula C. Teixeira for conceptualization (equal), data curation (equal), writing-original draft (equal), writingreview and editing (equal); Fernando S. Lameiras for conceptualization (equal), writing-original draft (equal), writing-review and editing (equal); Paulo Roberto G. Brandão for conceptualization (equal), writing-original draft (equal), writing-review and editing (equal), Rochel M. Lago for conceptualization (lead), data curation (lead), formal analysis (lead), investigation (lead), resources (lead), supervision (lead), writing-original draft (lead), writingreview and editing (lead).

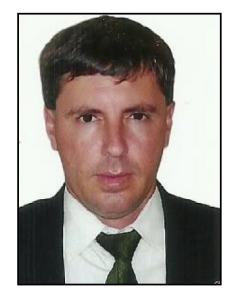

Ottavio R. D. R. Carmignano is graduated in Law (Faculdade Milton Campos, MG-Brazil, 1996) and has a master's degree in Socioeconomic Environmental Sustainability from the Universidade Federal de Ouro Preto (UFOP, MG-Brazil, 2015). He is Manager Partner of Pedras Congonhas Ltda. since 1992. His research is based on new applications for serpentinite rock in industrial markets. Currently, he is a PhD student in innovation at the Universidade Federal de Minas Gerais (UFMG, MG-Brazil).

Sara S. Vieira is a professor of Chemistry at Universidade Federal Fluminense (Brazil) since 2021. She received her PhD (2014) in Science from Universidade Federal de 


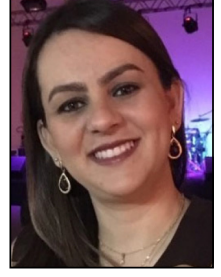

Lavras (Brazil) in partnership with the Center of Structural Chemistry of Instituto Superior Técnico (IST) of the University of Lisbon (Portugal). She did a Post-Doc at UNIFAL-MG, Brazil (2014-2016) and in the Chemistry Department at UFMG, Brazil (20162020), developing research involving the evaluation of potential adsorbents and catalysts based on mesoporous silicates, iron oxides, and mining residues. The studies mainly evaluated the applicability of these materials as catalysts for the production of biofuel and products of greater added value.

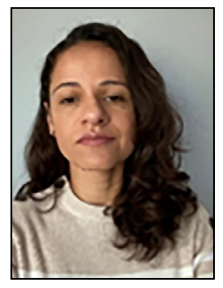

Ana Paula C. Teixeira is a professor of Chemistry at Universidade Federal de Minas Gerais (Brazil) since 2013. She received her $P h D$ in Inorganic Chemistry at this same university. She did a Post-Doc at Rice University (Houston, TX, USA, 2019-2020) developing research in the area of carbon materials for environmental application in the group of professor P. M. Ajayan. Her research interests include carbon materials synthesis for environmental applications and the use of mineral waste for technological applications.

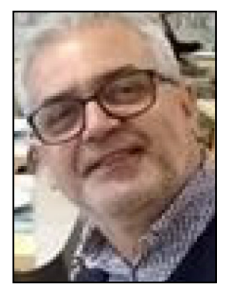

Fernando S. Lameiras is graduated in Physics from Universidade Federal de Minas Gerais (1976) with a Specialization in Nuclear Technology (UFMG/NUCLEBRÁS, 1978) and has a master's degree in Nuclear Science and Techniques (UFMG, 1982), and $P h D$ in Metallurgical and Mining Engineering (UFMG, 1991). He is a researcher at Centro de Desenvolvimento da Tecnologia Nuclear (CDTN) since 1977 and a professor at the Post-Graduate Program in Science and Technology of Radiation, Minerals, and Materials (master's and doctorate). He works in the area of materials engineering (nuclear fuel, ceramic materials, gem processing). Since 2005 he has been involved in the use of mining tailings in Portland cement and alkali-activated materials.

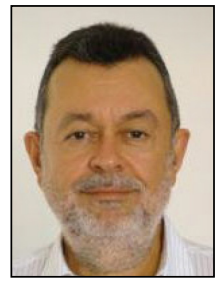

Paulo Roberto G. Brandão is a Mining Engineer (Universidade Federal de Minas Gerais, 1968). He obtained master's and PhD degrees from the University of British Columbia, Vancouver, Canada, in 1982. He is a professor of the Department of
Mining Engineering at Universidade Federal de Minas Gerais. He retired in 2003 and was awarded the title of Professor Emeritus. His areas of interest include ores and industrial minerals characterization and processing; reagents for minerals processing; recycling of mineral wastes, aggregation, and dispersion of mineral slurries; ironmaking, ceramics, and refractories.

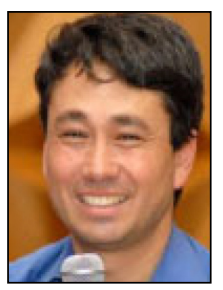

Rochel M. Lago is graduated from the University of Campinas (UNICAMP, São Paulo State, Brazil) with MSc under the supervision of Prof Ulf Schuchardt. In 1992, he spent one year at Gifu University (Japan) followed by a PhD at Oxford University (United Kingdom) under the supervision of Prof M. L. H. Green and a PostDoc with Prof J. L. G Fierro at the Institute of Catalysis and Petrochemistry (Madrid, Spain) working always in the area of catalysis. In 2005, he went to the University of Montreal (Canada) as a Visiting Researcher at the laboratories of Prof Richard Martel to work with carbon nanotubes and a Post-Doc at the business school HEC (Heutes Etudes Commerciales, Canada) with Prof L. J. Filion on the theme of technological entrepreneurship. He works at the Department of Chemistry at Universidade Federal de Minas Gerais (UFMG, Minas Gerais State, Brazil) since 1997.

\section{References}

1. Ferreira, H.; Leite, M. G. P.; J. Cleaner Prod. 2015, 108, 1081.

2. Usman, U. A.; Yusoff, I.; Raoov, M.; Hodgkinson, J.; Environ. Earth Sci. 2019, 78, 615.

3. Banerjee, R.; Goswami, P.; Mukherjee, A. In BioGeotechnologies for Mine Site Rehabilitation; Prasad, MNV.; Favas, P. J. C.; Maiti, S. K., eds.; Elsevier: Amsterdam, 2018, p. 393-413.

4. U.S. Geological Survey; Mineral Commodity Summaries 2020; Washington, USA, 2020, available at https://pubs.usgs.gov/ periodicals/mcs2020/mcs2020.pdf, accessed in June 2021.

5. Agência Nacional de Mineração; Anuário Mineral Brasileiro Principais Substâncias Metálicas; Brasília, 2019, available at https://www.gov.br/anm/pt-br/centrais-de-conteudo/ publicacoes/serie-estatisticas-e-economia-mineral/anuariomineral/anuario-mineral-brasileiro/copy_of_AMB2019_ anobase2018_FINAL.pdf/view, accessed in June 2021.

6. Agência Nacional de Mineração Anuário Mineral Brasileiro: Principais Substâncias Metálicas; Brasília, 2020, available at https://www.gov.br/anm/pt-br/centrais-de-conteudo/ publicacoes/serie-estatisticas-e-economia-mineral/anuariomineral/anuario-mineral-brasileiro/amb_2020_ano_ base_2019_revisada2_28_09.pdf, accessed in June 2021. 
7. Gomes, R. B.; Tomi, G. D.; Assis, P. S.; Miner. Eng. 2015, 70, 201.

8. Fundação Estadual do Meio Ambiente (FEAM); Inventário de Resíduos Sólidos da Mineração Ano Base 2017; FEAM: Belo Horizonte, 2018, p. 47, available at http://www. feam.br/images/stories/2018/RESIDUOS/Inventario_ Minera\%C3\%A7\%C3\%A3o_ano_base_2017.pdf, accessed in July 2021.

9. Instituto Brasileiro de Mineração (IBRAM); Informações $e$ Análises da Economia Mineral Brasileira; 2012, available at http://login.webadvisor.com.br/sites/1300/1382/00004430.pdf, accessed in June 2021.

10. Yang, C.; Cui, C.; Qin, J.; Cui, X.; Constr. Build. Mater. 2014, 70,36 .

11. Filippov, L. O.; Severov, V. V.; Filippova, I. V.; Int. J. Miner. Process. 2014, 127, 62.

12. Roy, S. K.; Nayak, D.; Rath, S. S.; Powder Technol. 2020, 367, 796.

13. Lima, R. M. F.; Abreu, F. P. V. F.; J. Mater. Res. Technol. 2020 , 9, 2021.

14. Araujo, A. C.; Amarante, S. C.; Souza, C. C.; Silva, R. R. R.; Miner. Process. Extr. Metall. 2003, 112, 54.

15. Nakhaei, F.; Irannajad, M.; Miner. Process. Extr. Metall. Rev. 2018, 39, 89.

16. Maré, E.; Beven, B.; Crisafio, C. In Iron Ore, $1^{\text {st }}$ ed.; Lu, L., ed.; Elsevier: Amsterdam, 2015, p. 309-338.

17. Departamento Nacional de Produção Mineral (DNPM); Portaria No. 237, de 18 de outubro de 2001, Aprova as Normas Reguladoras de Mineração (NRM), de que trata o Art. 97 do Decreto-Lei No. 227, de 28 de fevereiro de 1967, available at https://supremoambiental.com.br/wp-content/uploads/2016/10/ portaria-n.-237-dnpm-2001-normas-reguladoras-de-mineracaonrm.pdf, accessed in June 2021.

18. Matiolo, E.; Couto, H. J. B.; Lima, N.; Silva, K.; de Freitas, A. S.; Miner. Eng. 2020, 158, 106608.

19. Silva, R. C. F.; Ardisson, J. D.; Cotta, A. A. C.; Araujo, M. H.; Teixeira, A. P. C.; Environ. Pollut. 2020, 260, 114099.

20. Alves, W.; Ferreira, P.; Araújo, M.; Resour. Policy 2020, 101648.

21. Liu, Y.; Du, F.; Yuan, L.; Zeng, H.; Kong, S.; J. Hazard. Mater. 2010, 178, 999.

22. Xu, D. M.; Zhan, C. L.; Liu, H. X.; Lin, H. Z.; Environ. Sci. Pollut. Res. 2019, 26, 35657.

23. Zhang, S.; Xue, X.; Liu, X.; Duan, P.; Yang, H.; Jiang, T.; Wang, D.; Liu, R.; J. Min. Sci. 2006, 42, 403.

24. Devi, B.; Natesh, M. G.; Praveen, K.; Archana, N.; Sogi, A.; Civ. Environ. Res. 2015, 7, 18.

25. dos Santos, C. R.; Filho, J. R. A.; Tubino, R. M. C.; Schneider, I. A. H.; Geomaterials 2013, 3, 54.

26. U.S. Geological Survey (USGS); Mineral Commodity Summaries; Washington, USA, 2019, available at https:// bookstore.gpo.gov/products/mineral-commoditysummaries-2019, accessed in June 2021.
27. Fontes, W. C.; de Carvalho, J. M. F.; Andrade, L. C. R.; Segadães, A. M.; Peixoto, R. A. F.; Constr. Build. Mater. 2019, 206, 111.

28. Falconi, I. B. A.; Baltazar, M. P. G.; Espinosa, D. C. R.; Tenório, J. A. S.; Can. J. Chem. Eng. 2020, 98, 1069.

29. Orlando, M. T. D’A.; Galvão, E. S.; Cavichini, A. S.; Rangel, C. V. G. T.; Orlando, C. G. P.; Grilo, C. F.; Soares, J.; Oliveira, K. S. S.; Sá, F.; Costa Jr., A.; Bastos, A. C.; Quaresma, V. S.; Chemosphere 2020, 257, 127184.

30. Figueiredo, M. D.; Lameiras, F. S.; Ardisson, J. D.; Araujo, M. H.; Teixeira, A. P. C.; Integr. Environ. Assess. Manage. 2020, $16,636$.

31. Hatje, V.; Pedreira, R. M. A.; de Rezende, C. E.; Schettini, C. A. F.; de Souza, G. C.; Marin, D. C.; Hackspacher, P. C.; Sci. Rep. 2017, 7, 10706.

32. Thompson, F.; de Oliveira, B. C.; Cordeiro, M. C.; Masi, B. P.; Rangel, T. P.; Paz, P.; Freitas, T.; Lopes, G.; Silva, B. S.; Cabral, A. S.; Soares, M.; Lacerda, D.; Vergilio, C. S.; Lopes-Ferreira, M.; Lima, C.; Thompson, C.; de Rezende, C. E.; Sci. Total Environ. 2020, 705, 135914.

33. Srivastava, M.; Pan, S.; Prasad, N.; Mishra, B.; Int. J. Miner. Process. 2001, 61, 93.

34. Zuccheratte, A. C. V.; Freire, C. B.; Lameiras, F. S.; Constr. Build. Mater. 2017, 151, 859.

35. Fontes, W. C.; Mendes, J. C.; da Silva, S. N.; Peixoto, R. A. F.; Constr. Build. Mater. 2016, 112, 988.

36. Galvão, J. L. B.; Andrade, H. D.; Brigolini, G. J.; Peixoto, R. A. F.; Mendes, J. C.; J. Cleaner Prod. 2018, 200, 412.

37. Weishi, L.; Guoyuan, L.; Ya, X.; Qifei, H.; J. Cleaner Prod. 2018, 204, 685.

38. da Silva, F. L.; Araújo, F. G. S.; Teixeira, M. P.; Gomes, R. C.; von Krüger, F. L.; Ceram. Int. 2014, 40, 16085.

39. de Melo, V. A. R.; Lameiras, F. S.; Tolentino, E.; Mater. Res. 2011, 15, 15.

40. Bicalho, H. A.; Rios, R. D. F.; Binatti, I.; Ardisson, J. D.; Howarth, A. J.; Lago, R. M.; Teixeira, A. P. C.; J. Hazard. Mater. 2020, 400, 123310.

41. Prates, C. D.; Ballotin, F. C.; Limborço, H.; Ardisson, J. D.; Lago, R. M.; Teixeira, A. P. C.; Appl. Catal., A 2020, 600, 117624.

42. Cheng, Y.; Huang, F.; Li, W.; Liu, R.; Li, G.; Wei, J.; Constr. Build. Mater. 2016, 118, 164.

43. Duan, P.; Yan, C.; Zhou, W.; Ren, D.; Ceram. Int. 2016, 42, 13507.

44. Yang, C.; Cui, C.; Qin, J.; Ceram. Int. 2015, 41, 1213.

45. Zheng, J.; Gao, Z.; He, H.; Yang, S.; Sun, C.; Chemosphere 2016, 150, 40.

46. Augusto, T. D. M.; Chagas, P.; Sangiorge, D. L.; Mac Leod, T. C. D. O.; Oliveira, L. C. A.; Castro, C. S.; J. Environ. Chem. Eng. 2018, 6, 6545.

47. de Freitas, V. A. A.; Breder, S. M.; Silvas, F. P. C.; Rouse, P. R.; de Oliveira, L. C. A.; Chemosphere 2019, 219, 328. 
48. Sant'ana Filho, J. N.; da Silva, S. N.; Silva, G. C.; Mendes, J. C.; Peixoto, R. A. F.; J. Mater. Civ. Eng. 2017, 29, 04017104-1.

49. Chen, Y.; Zhang, Y.; Chen, T.; Liu, T.; Huang, J.; Constr. Build. Mater. 2013, 38, 1083.

50. Giri, S. K.; Das, N. N.; Pradhan, G. C.; Powder Technol. 2011, $214,513$.

51. Stević, D.; Mihajlović, D.; Kukobat, R.; Hattori, Y.; Sagisaka, K.; Kaneko, K.; Atlagić, S. G.; J. Mater. Eng. Perform. 2016, 25,3121 .

52. Pereira, O. C.; Bernardin, A. M.; J. Hazard. Mater. 2012, 233234, 103.

53. Geng, H.; Wang, F.; Yan, C.; Tian, Z.; Chen, H.; Zhou, B.; Yuan, R.; Yao, J.; J. Hazard. Mater. 2020, 383, 121136.

54. ABNT NBR 10004: Resíduos Sólidos: Classificação, ABNT: Rio de Janeiro, 2004, p. 5.

55. Sakthivel, R.; Das, B.; Satpati, B.; Mishra, B. K.; Appl. Surf. Sci. 2009, 255, 6577.

56. Defáveri, K. C. S.; dos Santos, L. F.; Carvalho, J. M. F.; Peixoto, R. A. F.; Brigolini, G. J.; Constr. Build. Mater. 2019, 220, 375.

57. Ma, B.-g.; Cai, L.-X.; Li, X.-g.; Jian, S.-w.; J. Cleaner Prod. 2016, 127, 162.

58. Bai, S.; Tian, G.; Gong, L.; Tang, Q.; Meng, J.; Duan, X.; Liang, J.; Chem. Eng. Res. Des. 2020, 159, 543.

59. Dong, G.; Tian, G.; Gong, L.; Tang, Q.; Li, M.; Meng, J.; Liang, J.; Microporous Mesoporous Mater. 2020, 305, 110352.

60. Das, S. K.; Kumar, S.; Ramachandrarao, P.; Waste Manage. 2000, 20, 725.

61. Duan, P.; Yan, C.; Zhou, W.; Ren, D.; Constr. Build. Mater. 2016, 118, 76.

62. Cornell, R. M.; Schwertmann, U.; The Iron Oxides: Structure, Properties, Reactions, Occurrences and Uses, vol. 53, $2^{\text {nd }}$ ed.; John Wiley \& Sons: Hoboken, Nova Jersey, 2006.

63. Carrasco, E. V. M.; Magalhaes, M. D. C.; Santos, W. J. D.; Alves, R. C.; Mantilla, J. N. R.; Constr. Build. Mater. 2017, 131, 31.

64. Almeida, J.; Ribeiro, A. B. B.; Silva, A. S.; Faria, P.; J. Build. Eng. 2020, 29, 101215.

65. Cheng, Y.; Huang, F.; Qi, S.; Li, W.; Liu, R.; Li, G.; Constr. Build. Mater. 2020, 242, 118147.

66. Lu, C.; Yang, H.; Wang, J.; Tan, Q.; Fu, L.; Sci. Total Environ. 2020, 736, 139483.

67. Izidoro, J. C.; Kim, M. C.; Bellelli, V. F.; Pane, M. C.; Botelho Jr., A. B.; Espinosa, D. C. R.; Tenório, J. A. S.; J. Sustainable Minery 2019, 18, 277.

68. Cristiano, D. M.; Mohedano, R. A.; Nadaleti, W. C.; de Castilhos Jr., A. B.; Lourenço, V. A.; Gonçalves, D. F. H.; Filho, P. B.; Renewable Energy 2020, 154, 151.

69. dos Santos, A. J.; Cunha, G. S.; Cruz, D. R. S.; Romão, L. P. C.; Martínez-Huitle, C. A.; J. Electroanal. Chem. 2019, 848, 113330 .

70. Jadhav, D. A.; Ghadge, A. N.; Ghangrekar, M. M.; Bioresour. Technol. 2015, 191, 110.
71. Mendes, B. C.; Pedroti, L. G.; Fontes, M. P. F.; Ribeiro, J. C. L.; Vieira, C. M. F.; Pacheco, A. A.; de Azevedo, A. R. G.; Constr. Build. Mater. 2019, 227, 116669.

72. Chen, Y.; Zhang, Y.; Chen, T.; Zhao, Y.; Bao, S.; Constr. Build. Mater. 2011, 25, 2107.

73. Yellishetty, M.; Karpe, V.; Reddy, E. H.; Subhash, K. N.; Ranjith, P. G.; Resour., Conserv. Recycl. 2008, 52, 1283.

74. Gou, M.; Zhou, L.; Then, N. W. Y.; Sci. Eng. Compos. Mater. 2019, 26, 449.

75. Sunil, B. M.; Manjunatha, L.s.; Yaragal, S.; Adv. Concr. Constr. 2017, 5, 671.

76. Zhao, S.; Fan, J.; Sun, W.; Constr. Build. Mater. 2014, 50, 540.

77. ABNT NBR 9781: Peças de Concreto para Pavimentação Especificação e Métodos de Ensaio, ABNT: Rio de Janeiro, 2013, p. 26.

78. Gou, M.; Zhou, L.; Then, N. W. Y.; Xu, D.-M.; Zhan, C.-L.; Liu, H.-X.; Lin, H.-Z.; Zuccheratte, A. C. V.; Freire, C. B.; Lameiras, F. S.; Qi, C.; Fourie, A.; Gayana, B. C.; Chandar, K. R.; da Silva, F. L.; Araújo, F. G. S.; Teixeira, M. P.; Gomes, R. C.; von Krüger, F. L.; Qi, C.; Fourie, A.; Sci. Eng. Compos. Mater. 2019, 26, 35657.

79. Kuranchie, F. A.; Shukla, S. K.; Habibi, D.; Int. J. Min., Reclam. Environ. 2016, 30, 92.

80. Davidovits, J.; Geopolymer Chemistry and Applications, $5^{\text {th }}$ ed.; Institut Géopolymère, Geopolymer Institute, S.-Q.: France, 2015.

81. Prim, S. R.; Folgueras, M. V.; de Lima, M. A.; Hotza, D.; J. Hazard. Mater. 2011, 192, 1307.

82. Zhang, P.; Li, S.; Guo, P.; Zhao, X.; Langmuir 2020, 36, 6160.

83. Wu, S.; Sun, A.; Zhai, F.; Wang, J.; Xu, W.; Zhang, Q.; Volinsky, A. A.; Mater. Lett. 2011, 65, 1882.

84. Giri, S. K.; Das, N. N.; Pradhan, G. C.; Colloids Surf., A 2011 , $389,43$.

85. Liu, P.; Gu, X.; Zhang, Z.; Shi, J.; Rao, J.; Bian, L.; Minerals 2019, 9, 648.

86. Guerreiro, G. G.; de Andrade, F. V.; de Freitas, M. R.; Ceram. Int. 2020, 46, 29271.

87. Iakovleva, E.; Maydannik, P.; Ivanova, T. V.; Sillanpää, M.; Tang, W. Z.; Mäkilä, E.; Salonen, J.; Gubal, A.; Ganeev, A. A.; Kamwilaisak, K.; Wang, S.; J. Cleaner Prod. 2016, 133, 1095.

88. Yuan, X.; Xia, W.; An, J.; Zhou, X.; Xiang, X.; Yin, J.; Yang, W.; Desalin. Water Treat. 2017, 98, 222.

89. Morais, M. B.: Modificações do Rejeito da Samarco Rico em Ferro para Uso como Adsorventes; MSc Dissertation, Programa de Pós-Graduação Multicêntrico em Química de Minas Gerais, Universidade Federal de Viçosa, Florestal, 2018, available at https://locus.ufv.br//handle/123456789/24397, accessed in June 2021.

90. Sima, T. V.; Letshwenyo, M. W.; Lebogang, L.; Environ. Technol. Innovation 2018, 11, 49. 
91. Suh, Y. J.; Kil, D. S.; Jang, H. D.; Cho, K.; Geosyst. Eng. 2015, $18,205$.

92. Wang, Y.; Wang, Y.; Luo, S.; Jiang, M.; Liu, C.; Teng, F.; Chen, H.; Shen, H.; Gao, D.; Ionics 2020, 26, 1645.

93. Revista Pesquisa FAPESP; Rejeitos da Mineração; ed. 240, 2016, p. 14, available at https://revistapesquisa.fapesp.br/ revista/ver-edicao-editorias/?e=240, accessed in June 2021.

94. Briz, J.; Pesquisa da UFMG Aproveita Rejeitos de Mineração na Construção Civil; Revista Minérios \& Minerales, available at https://revistaminerios.com.br/pesquisa-ufmg/, accessed in June 2021.

95. Associação Brasileira de Metalurgia, Materiais e Mineração (ABM); Vale Inaugura Fábrica que Transforma Rejeitos da Mineração em Produtos para a Construção Civil; https:// www.abmbrasil.com.br/por/noticia/vale-inaugura-fabricaque-transforma-rejeitos-em-produtos-para-a-construcao-civil, accessed in June 2021.
96. Pantano, G.; Grosseli, G. M.; Mozeto, A. A.; Fadini, P. S.; Quim. Nova 2016, 39, 732.

97. da Gama, E. M.; Os Coprodutos da Mineração de Ferro para uma Economia Sustentável: Coprodutos para Mineração Economia Circular; Ed. Novas Edições Acadêmicas: Beau Bassin-Rose Hill, 2019.

98. Lei No. 14.066, de 30 de setembro de 2020, Altera a Lei No. 12.334, de 20 de setembro de 2010, que Estabelece a Política Nacional de Segurança de Barragens (PNSB), a Lei No. 7.797, de 10 de julho de 1989, que Cria o Fundo Nacional do Meio Ambiente (FNMA), a Lei No. 9.433, de 8 de janeiro de 1997, que Institui a Política Nacional de Recursos Hídricos, e o DecretoLei No. 227, de 28 de fevereiro de 1967 (Código de Mineração), Diário Oficial da União (DOU), Brasília, de 01/10/2020, p. 3.

Submitted: January 3, 2021 Published online: July 14, 2021 